\title{
"724" The First National Acute Stroke Treatment Plan in Iran
}

Masoud Mehrpour, MD'; Babak Zamani, MD'; Mehdi Shadnoush, PHD²; Jamshid Kermanchi, PHD²; Shiva Hozhabri, MD²; Mohammad Aghaali, MD³ ${ }^{3}$ Ashfaq Shuaib, MD'; Ehsan Sharifipour, MD $^{3 *}$

'Iranian Stroke Association, Iran University of Medical Sciences, Tehran, Iran

${ }^{2}$ Deputy of national transplantation and disease management center, Ministry of Health and Medical Education, Tehran, Iran

IIranian Stroke Association, Neuroscience Research Center, Qom University of Medical Sciences, Qom, Iran

${ }^{4}$ University of Alberta, Edmonton, Alberta, Canada

\section{Dear Editor,}

In Iran, with a population of more than 83 million, stroke as one of the main causes of adult mortality and disability, ${ }^{1}$ has an incidence rate higher than the global average and the age is about 10 years younger. ${ }^{2}$ Until recently, there was no national strategy to manage acute stroke. ${ }^{3}$ In 2014, with the collaboration of the Ministry of Health, and the Iranian Stroke Association, the National Scientific Workgroup with the academic elite were established to develop a comprehensive stroke strategy that reflects the national needs. ${ }^{4}$ A national plan was developed and implemented in 2016 with an emphasis on the diagnosis and treatment of acute stroke and was named the " 724 " Plan (means every 7 days a week and all 24 hours a day) with the growing trend of covering stroke patients across the country, step by step that continues to this day, with the following main components:

Motivation and Public Information in the Community Information about the various aspects of stroke was made available through cyberspace, journalism organizations, media, stroke campaigns, and health centers to raise public awareness. Special activities, including celebrations on the World Stroke Day, public lectures, meeting sessions with experts, and direct questions and answers in public spaces were offered nationwide.

Training of Personnel involved in the Treatment of Acute Stroke

All relevant groups, including senior and middlelevel managers, urban emergency stuffs, neurologists (individuals in charge of the plan in local centers), emergency medicine specialists, hospital staff, laboratories, imaging, nursing offices, blood banks, and selected rehabilitation centers were trained for the plan. ${ }^{5}$ A liaison was appointed between the national center and the participating hospital to monitor and report the coordination issues.
Inter-organizational Coordination between Relevant Components for Rapid Transfer of Patients

A code called SAMA (stroke pre-notification code) was defined for urban emergencies, hospitals, and universities when the stroke was suspected. As soon as a person with acute stroke symptoms within 6 hours from onset called the Dispatch Center, this code was announced to all relevant components (related stuff in the emergency service and 724 hospital) for emergency transfer of the patient.

\section{Establishment of Special Acute Stroke Care Units} Called SCU

Independent SCUs were launched in all selected hospitals and managed by special stroke-trained neurologists. ${ }^{6}$ They were also equipped with continuous monitoring facilities and medications and necessary supplies for stroke management. Independent public insurance for thrombolytic medication was provided to all eligible patients. The 'door-to-needle' time was monitored and we tried to be keep it under 60 minutes. ${ }^{6}$ Prevention measures against stroke complications were implemented, with access to dietary evaluation, stroke rehabilitation team (occupational therapists, and physiotherapists), speech and language specialists.

\section{National Registration and Reporting Database}

A national system was designed to record patients' information and response to treatment. At the initiation of the program in 2016, there were 55 centers. These increased to 110 by 2020 and continue to increase quantitatively and qualitatively. During the last four years since the implementation of the plan, more than 40000 patients with acute stroke have been treated. Approximately 7500 cases have received intravenous thrombolytic therapy and more than 300 cases of endovascular thrombectomy have been performed. Initial evaluations showed that the doorto-needle time continued to decrease every year (from a mean of $69.54 \pm 25.01$ minutes in 2016 to $55.1 \pm 40.22$ 
minutes in 2020), with increasing numbers of patients receiving thrombolytic therapy (from 784 in 2016 to 2106 in 2019) and endovascular thrombectomy (from 33 in 2016 to 399 in 2020) every year. We continue to acquire data prospectively to monitor the progress of the stroke implementation plan.

\section{Authors' Contribution}

$\mathrm{MM}, \mathrm{BZ}, \mathrm{MS}, \mathrm{JK}, \mathrm{ES}$, and SH had an effective role in the implementation of this project and the data collection. ES, SH, $\mathrm{MA}$, and AS were involved in the data extraction and analysis and writing the letter. All authors have contributed effectively to the final arrangement of this letter.

\section{Acknowledgments}

Appreciation for all those involved in the " 724 " National project, especially the national 724 scientific committee members.

\section{Conflict of Interest Disclosures}

None.

\section{Ethical Statement}

Not applicable.

\section{References}

1. Savadi Oskouie D, Sharifipour E, Sadeghi Bazargani H, Hashemilar M, Nikanfar M, Ghazanfari Amlashi S, et al. Efficacy of citalopram on acute ischemic stroke outcome: a randomized clinical trial. Neurorehabil Neural Repair. 2017;31(7):638-47. doi: 10.1177/1545968317704902.

Received: January 15, 2021, Accepted: March 3, 2021, ePublished: August 1, 2021
2. Azarpazhooh MR, Etemadi MM, Donnan GA, Mokhber $\mathrm{N}$, Majdi MR, Ghayour-Mobarhan M, et al. Excessive incidence of stroke in Iran: evidence from the Mashhad Stroke Incidence Study (MSIS), a population-based study of stroke in the Middle East. Stroke. 2010;41(1):e3-e10. doi: 10.1161/strokeaha.109.559708.

3. Ayromlou H, Soleimanpour H, Farhoudi M, SadeghiHokmabadi E, Rajaei Ghafouri R, Sharifipour E, et al. What are the most important barriers for thrombolytic therapy in ischemic stroke patients? Int J Stroke. 2013;8(4):E7. doi: 10.1111/ijs.12093.

4. Sadeghi-Hokmabadi E, Farhoudi M, Taheraghdam A, Hashemilar M, Savadi-Osguei D, Rikhtegar R, et al. Intravenous recombinant tissue plasminogen activator for acute ischemic stroke: a feasibility and safety study. Int J Gen Med. 2016;9:361-7. doi: 10.2147/ijgm.s112430.

5. Jauch EC, Saver JL, Adams HP Jr, Bruno A, Connors JJ, Demaerschalk BM, et al. Guidelines for the early management of patients with acute ischemic stroke: a guideline for healthcare professionals from the American Heart Association/American Stroke Association. Stroke. 2013;44(3):870-947. doi: 10.1161/STR.0b013e318284056a.

6. Powers WJ, Rabinstein AA, Ackerson T, Adeoye OM, Bambakidis NC, Becker K, et al. Guidelines for the early management of patients with acute ischemic stroke: 2019 update to the 2018 guidelines for the early management of acute ischemicstroke: a guideline for healthcare professionals from the American Heart Association/American Stroke Association. Stroke. 2019;50(12):e344-e418. doi: 10.1161/ str.0000000000000211.

Cite this article as: Mehrpour M, Zamani B, Shadnoush M, Kermanchi J, Hozhabri S, Aghaali M, et al. "724" The First National Acute Stroke Treatment Plan in Iran. Arch Iran Med. 2021;24(8):651-652. doi: 10.34172/aim.2021.92

(c) (1) 2021 The Author(s). This is an open-access article distributed under the terms of the Creative Commons Attribution License (http:// creativecommons.org/licenses/by/4.0), which permits unrestricted use, distribution, and reproduction in any medium, provided the original work is properly cited. 